\title{
Philosophical Theology and Rational Theology
}

\begin{abstract}
Vincent Brümmer's philosophical theology project has been of utmost importance for philosophers of religion, and will continue to be so for the next generation of such scholars. In this essay I defend his position against the objections to philosophical theology raised by Eberhard Herrmann. But I further argue that philosophers of religion must go beyond philosophical theology and also engage in rational theology. Once we have established the meaning and coherence of certain religious beliefs and their connection to other religious beliefs, philosophers should go on to ask whether it is rational to accept these beliefs in the first place; and, if not, should consider what religious people might believe instead. Whereas philosophical theology attempts to test the coherence of doctrinal claims, their implications and their connection to other doctrinal claims, rational theology attempts to test the rationality and warrant of these doctrinal claims and to explore their connection to philosophical, scientific, political and moral claims.
\end{abstract}

Vincent Brümmer's ideas about philosophical theology and his research within the field have had great impact on many scholars around the world. He has been invited to Uppsala University on a number of occasions and in 1994 was awarded an honorary doctorate there. Brümmer was one of those key figures in contemporary philosophy of religion whom I had to read when a young PhD student. Very soon I understood why, and his ideas have influenced my writing and teaching ever since.

In this essay I shall focus on the task of philosophical theology and will try to develop an account of it in dialogue with Brümmer and also with one of his critics, Eberhard Herrmann. Herrmann was the adviser for my PhD thesis and the professor who, at the time when Brümmer received the honorary doctorate, held the chair in philosophy of religion at Uppsala University. He represented a viewpoint quite different from that of Brümmer. Herrmann thought that we ought to distinguish clearly between, on the one hand, philosophical theology and, on the other, philosophy of religion, whereas Brümmer took them to be more or the less the same thing. My own worry has been a rather different one: that Brümmer's account leaves out important epistemological questions which need to be addressed by philosophers of religion. But maybe my concern is unwarranted. Brümmer has, after all, suggested that his "contextual approach to the theism-atheism debate is quite compatible with the project which Stenmark calls 'religious epistemology'"' (1999:94). I shall discuss this issue in the second half of the essay. To start with I want to explicate Brümmer's account of philosophical theology and then move on to Herrmann's objections.

\section{BRÜMMER'S PHILOSOPHICAL THEOLOGY}

What is Brümmer's view on philosophical theology and what alternative understandings of the enterprise and of philosophy of religion does he explicitly or implicitly reject? Brümmer maintains that the "task of philosophical theology is not to provide proofs of the truth (or falsity) of the Christian faith, or to find neutral rational grounds on which to justify accepting (or 
rejecting) the Christian, or any other, faith. Instead the philosophical theologian asks semantic and hermeneutical questions about the meaning and interpretation of the faith: what are the implications and presuppositions of the fundamental concepts of the faith, and how could the claims of the faith be interpreted in a coherent and relevant way? In this sense philosophical theology has an essential contribution to make in the theological quest of faith seeking understanding" (1992:2).

It is not only philosophical theology that Brümmer seems to understand in this way. He explicitly says that: "Philosophical reflection aims at clarifying and limiting our conceptual options" (1992:27). Philosophers reflect on possible conceptual forms in order to establish whether or not they are coherent and relevant, and in order to see what the implications would be if we were to accept them. Therefore the aim of philosophy is not necessarily to force conclusions but rather to limit and clarify our conceptual options and in this way to contribute to making progress in our thinking.

The extent of this limitation depends on the range of criteria that we use. Brümmer exemplifies three levels of reflection (1992:28):

1. Philosophical theology is the attempt to determine which conceptual forms, doctrines or religious beliefs can be accepted without contradiction and which, positively speaking, might be coherent.

2. Confessional theology is the attempt to determine which conceptual forms, doctrines or religious beliefs can be accepted without becoming untrue to the community of faith.

3. Personal theology or personal faith is each believer's attempt to determine which conceptual forms, doctrines or religious beliefs he or she can embrace without losing his or her integrity.

Because the criteria used in philosophical theology (consistency and coherence) are accessible not solely to religious believers but to all members of the community of scholars, it has a proper place within the revered precincts of the university (2006:453).

Brümmer further contrasts philosophical theology to three other forms of theology (2006:454-57):

1. Revealed theology is the attempt to base religious beliefs and doctrines on divine revelation or grounds internal to faith.

2. Natural theology is the attempt to rationally prove religious beliefs by appealing to universally accepted or neutral grounds.

3. Descriptive theology is the attempt to describe religious beliefs and practices and test the truth of these descriptions (and not the beliefs and practices themselves).

Unlike revealed theology, philosophical theology treats revelatory or doctrinal claims merely as assumptions (and not as truths) when testing their coherence, implications and connection to other revelatory or doctrinal claims. Unlike natural theology, philosophical theology seeks to analyze the meaning of doctrine rather than attempting to prove its truth. And, unlike descriptive theology, philosophical theology tries to make an innovative contribution to the conceptualization of a religious tradition. However, like descriptive theology and religious studies, philosophical theology takes not God but religion, and in particular the doctrinal conceptions of God or faith, as its object of inquiry.

\section{HERRMANN'S OBJECTIONS}

Let me now contrast Brümmer's view with that propounded by Herrmann. Herrmann's view is that philosophical theology is a theological discipline, whereas philosophy of religion is a philosophical discipline, and therefore philosophers of religion should not be philosophical 
theologians, which too often is the case. Philosophy of religion, in contrast to philosophical theology (which is the intellectual manifestation of a religious view of life by means of philosophical tools), belongs among the studies of religion (Herrmann 1995:14).

In fact, according to Herrmann, there is no place for philosophical theology at the university. He writes: "Theological reflection which explicitly or implicitly starts out from a given denominational or religious framework, aims at defending a definite point of view, rendering it more secure or at least undermining objections to it. ... The aim [of philosophical reflection], however, is more a matter of being able to raise certain questions which help us to understand how things are related, and to solve problems, rather than a matter of defending a particular viewpoint. In simple terms, we can express the difference like this: whereas in philosophy we concentrate on questions without knowing the answers in advance, in theology we adopt a position towards answers that have already been given" (2004:30). Herrmann maintains that we should not blend religious and philosophical arguments, a practice which is quite common in the philosophy of religion, but instead we should reason strictly philosophically without presupposing either theoretical adherence to a historically given religious tradition or personal religious commitment (2007:163).

To what extent would this kind of critique target Brümmer's philosophical theology? It is true that Brümmer's philosophical theology starts out, explicitly or implicitly, from a given denominational or religious framework. Often, as Brümmer points out, philosophical theologians are interested in analyzing the meaning of their own faith or the religious tradition to which they themselves belong (2006:459). In this regard Herrmann's characterization of philosophical theology as the intellectual manifestation of a religious view of life by means of philosophical tools seems to apply to Brümmer. But Brümmer also maintains that in principle anyone can analyze the meaning of the doctrines of any one of the religions of the world. So it is, at the most, a conditional intellectual manifestation of a religious view of life. However, I do think that we have a problem if too many philosophers focus on just one religion, or one particular conception of God. This has indeed been a problem, because the amazing revival of philosophical theology which we have seen since the 1980s (and in which Brümmer has played a key role) has focused almost exclusively on classical theism. So what we need to develop today is a multi-religious and multi-confessional philosophical theology. Moreover, Brümmer's conception of philosophical theology is compatible with such a development.

Now Herrmann seems to believe that there is something wrong in principle, or at least something unphilosophical, about starting either from a theoretical adherence to a historically given religious tradition or from a personal religious commitment. That is something which theologians might do, but which philosophers should not. Philosophers should instead concentrate on questions without knowing the answers in advance. They ought to raise certain questions which help us to understand how things are related, and to solve problems, rather than start from or defend a particular viewpoint.

Certainly we should agree with Herrmann that there is something unphilosophical about assuming at the outset that we know the truth. The genuine inquirer wants to get to the truth, whether or not that truth comports with what he or she believed when embarking on the investigation. If we do not genuinely seek the truth in this way, the risk we run is of becoming what Susan Haack has named the sham reasoner: "The sham reasoner is not primarily concerned to find out how things really are, but to make a case for some immovably held preconceived belief" (1996:298).

Is this a problem for Brümmer? As far as I can see, the only truth that Brümmer's philosophical theology is based on is that "a basic presupposition of philosophical theology" is "that coherent theo-logy or God-talk is possible" (1992:3). In fact, he tries to defend this truth against those 
theologians who claim that God is "Wholly Other" and that in consequence the idea that we should interpret the claims of faith in a logically coherent way is illegitimate.

We can also contrast philosophical theology with philosophical atheology, which would be the attempt to show that the existence of any being that meets standard divine specifications is impossible or incoherent. A number of atheistic philosophers of religion are engaged in this kind of project today (Grim 2007 and Rundle 2007).

\section{PROBLEMS WITH HERRMANN'S OBJECTIONS}

Here we have come across a problem with Herrmann's position, because it appears to undercut much work philosophers do, not merely within philosophical theology but also within philosophy of religion and, so I shall argue, within philosophy in general.

Herrmann seems to anticipate these consequences for philosophy in general because he also writes: "Something similar [as in philosophical theology] applies to various types of ideology where philosophical methods are subordinated to the aim of confirming one particular position and refuting competing alternatives. Very often philosophical questions revolve around things which are taken to be self-evident e.g. to treat the assertion 'God exists' as a statement of fact, a necessary precondition for being considered a believer according to many believers and also critics of religion. Metaphysical realism functions for a number of theologians and theistic and atheistic philosophers of religion as a precondition which is not open to debate" (2004:30-31).

Herrmann does not give us any names of philosophers who have proceeded in this way, but let me give some examples to illustrate the problem (if it is a problem). Thomas Morris writes in his introduction to a book in philosophical theology that it is "the shared assumption of these authors that religion, in particular the Judaeo-Christian religious tradition, is not just a domain of poetry, imagery, mystical transport, moral directive, and noncognitive existential self-understanding. Interacting especially with the philosophical developed tradition of Christian theology, they join the vast majority of the other leading contributors to contemporary philosophical theology in taking for granted theological realism, the cognitive stance presupposed by the classical theistic concern to direct our thoughts as well as our lives aright. It has been the intent of theologians throughout most of the history of the Christian faith to describe correctly, within our limits, certain important facts about God, human beings, and the rest of creation given in revelation and fundamental to the articulation of any distinctively Christian world view" (1988:3).

James Robert Brown gives us a description of a quite different group of philosophers (to which he himself belongs). Even if it is not easy to say exactly what naturalism is, Brown's idea is that naturalists "are motivated by the thought that the natural world is all that there is and the scientific approach is the only way to comprehend it. There is no god, nor any corresponding religious understanding of the world. ... Naturalism is a [research] program. Its aim is to eliminate, or reinterpret, or somehow explain away all norms and other apparently unnatural entities" (2001:118-19). John Searle writes that there "is a sense in which materialism is the religion of our time, at least among most of the professional experts in the fields of philosophy, psychology, cognitive science, and other disciplines that study the mind. Like more traditional religions, it is accepted without question and it provides the framework within which other questions can be posed, addressed, and answered" (2004:34). Philip Kitcher maintains that the "challenge is to develop a well-articulated and convincing version of secular humanism. Meeting that challenge is, I claim, one of the central problems of philosophy today" (2010:1). These philosophers do not merely study naturalism (cf. descriptive theology), nor do they merely suggest ways to conceptually improve naturalism (cf. philosophical theology), they are, when they consider it relevant, naturalists, materialists or secular humanists in their philosophical reasoning. 
Alvin Plantinga says in Warranted Christian Belief that he is engaged in two projects: "The first is addressed to everyone, believer and nonbeliever alike; it is intended as a contribution to an ongoing public discussion of the epistemology of Christian belief; it does not appeal to specifically Christian premises or presuppositions. I shall argue that, from this public point of view, there isn't the faintest reason to think that Christian belief lacks justification, rationality, or warrant - at least no reason that does not presuppose the falsehood of Christian belief. The other project, however - the project of proposing an epistemological account of Christian belief from a Christian perspective - will be of special interest to Christians. Here the project is that of starting from an assumption of the truth of Christian belief and from that standpoint investigating its epistemology, asking whether and how such belief has warrant. We might think of this project as a mirror image of the philosophical naturalist's project, when he or she assumes the truth of naturalism and then tries to develop an epistemology that fits well with that naturalistic standpoint" (2000:xiii-xiv).

In the other camp with Herrmann we have philosophers such as Michael Dummett, who writes: "Because I think there is this hierarchical order within philosophy, it would be wrong to allow any preconception of how things ought to come out to influence what one does lower down. You have to follow the argument and see where it leads. ... People take a whole set of views for granted, including a rather irritating scientism and materialism. Technical problems in semantics are of genuine relevance to philosophy, but they should always develop against a background of real philosophical puzzlement or wonder." ${ }^{1}$ Dummett is a Christian, but does not want to begin his philosophizing from a Christian preconception of how things are or should be; rather he wishes to follow the arguments wherever they might lead.

So what should we say? I would say that this range of contested approaches is simply how philosophy is done today! Some philosophers take a particular perspective or research program for granted in their philosophizing. They try to develop the program, apply it to new questions and sometimes defend it against objections, even if they are aware that not all philosophers embrace their perspective or research program (philosophical approach 1). Other philosophers do not subscribe to a particular perspective or research program. Rather they are interested in certain philosophical problems and do not beforehand have any clear ideas what the solution to these problems might be, or even within which theoretical framework the solution should be sought (philosophical approach 2).

This dispute might go very deep indeed and be grounded in different conceptions of the nature of philosophy. Plantinga, for instance, thinks that "philosophy is in large part a clarification, systematization, articulation, relating and deepening of pre-philosophical opinion. We come to philosophy with a range of opinions about the world and humankind and the place of the latter in the former; and in philosophy we think about these matters, systematically articulate our views, put together and relate our views on diverse topics, and deepen our views by finding unexpected interconnections and by discovering and answering unanticipated questions" (1984:268). So it should not surprise us that he is a spokesperson from philosophical approach 1.

On the other hand, maybe we need not take the issue to such a deep level, because it might rather be seen as a manifestation more of a methodological difference than of divergent accounts of what philosophy fundamentally is. If this is the case, we might in our work as philosophers sometimes use approach 1 and at other times approach 2. For instance, in my research on different models of rationality I did not have any real idea beforehand what model I would end up arguing for. But when I analyzed scientism I knew from the outset that (with great likelihood) I would reach the conclusion that it is a philosophically unsustainable view (Stenmark 1995 and 2001).

1 Dummett in conversation with Pyle (1999:6). 
In conclusion, if we were to accept Herrmann's view, we would have to consider much of the work undertaken by contemporary philosophers to be unphilosophical, and this is a road we do not have to take. Rather, we might point out that it is important that philosophy in general, and philosophy of religion and philosophical theology in particular, are disciplines which are characterized by a diversity of perspectives and constitute an environment in which everything is open to question and critical evaluation, by anyone wishing to become engaged in the inquiry. Furthermore, there is nothing in Brümmer's account of philosophical theology that would not satisfy this requirement, even though it is clearly a species of philosophical approach 1.

\section{RATIONAL THEOLOGY}

My own worries about Brümmer's philosophical theology have been different in kind from Herrmann's. Sometimes I get the impression that philosophical theology is the only thing Brümmer thinks that philosophers of religion should do. More precisely, my worry has been that his account sets aside urgent epistemological questions which go beyond those conceptual issues which philosophical theologians legitimately should deal with.

Maybe the reason we seem to part company on this issue has to do with different understandings of the nature of philosophy? Brümmer, as we have seen, maintains that philosophical reflection aims at clarifying, limiting and improving our conceptual options. Philosophers reflect on possible conceptual forms in order to establish whether they are coherent and relevant, and in order to see what the implications would be if we accepted them. The aim of philosophy is to limit and clarify our conceptual options and in this way contribute to making progress in our thinking. But, and this is important, he does not, unlike certain other philosophers influenced by Wittgenstein, simply want to leave things as they are, but thinks that a central task for philosophers is also to suggest conceptual innovations. Yet, all in all, philosophy is conceptual analysis.

I see philosophy rather as an inquiry whose mission is to provide tenable answers to our "Big Questions" regarding human beings, the world, and our place within its scheme of things. ${ }^{2}$ Philosophizing is a matter of truth estimation in the light of experience regarding these large issues which define its area of inquiry. Part of this is conceptual analysis, but, in my view, philosophy can and should also strive to give us knowledge, or at least rationally justified beliefs, about the answers to our Big Questions. Philosophy is a kind of truth-seeking and is, in that sense, like the sciences, although the methods used and topics explored are quite different. Though I want to hint at this, I am not going to explore these possible different understandings of philosophy any further in this essay, but shall now go directly to the epistemological issues.

Central tasks, as I see it, for philosophers of religion - besides doing philosophical theology - are as follows. The descriptive task $(\mathrm{A})$ is to investigate how people (both on an individual and a collective level, in different religions, in different cultures, in different historical periods, and of different social status, colour, and sex) form, reject, revise, and replace their religious beliefs. In short, the aim is to explicate the epistemological norms of actual religious practices. The normative task (B) is to evaluate critically these norms and the cognitive behaviour of people in regard to religious matters, and, if necessary, to suggest ways of improving them. In essence, the task is to assess the rationality, justification, and general epistemic status of religion (Stenmark 1998:264 and 2004:52f).

2 Such as: What is the nature of reality, the purpose of the universe, and the meaning of life? Is there a God? Why am I here? Do I have a soul? What happens when we die? Do we have free will? Why should I be moral? What is morally right and what is wrong? What can we know about these things? What are the limits of our knowledge, or of scientific knowledge? 
Brümmer has expressed misgivings about task (A). He maintains that "the task of philosophy in general and of philosophy of religion (or philosophical theology) in particular, is not to describe our various (religious) forms of thought, but to develop innovative proposals for keeping our conceptual forms coherent and credible as well as relevant and adequate for the changing demands of life. In fact, I would be inclined to say that the task of describing the variety and changes in our ways of thinking belongs to the historian and the social scientist and not to the philosopher" (1999:96). This negative response goes back, I think, to his evaluation of descriptive theology. Philosophical theologians should not describe the religious doctrines or beliefs but develop innovative proposals. The problem with this response is that I am not certain that the historian and the social scientist have the necessary expertise to explicate the epistemological norms of actual religious practices. I do not think they know enough about epistemology to ask the right kinds of question and to have the theories one needs to capture religious belief formation, revision and rejection. Maybe I am wrong here and, anyway, a fruitful cooperation between the philosopher on the one hand, and the historian and the social scientist on the other, might be the very best option!

What about task (B)? Just as Brümmer is critical against descriptive theology, he is equally so against natural theology. The task of philosophical theology is not to provide proofs of the truth (or falsity) of the Christian faith, or to find neutral rational grounds on which to justify accepting (or rejecting) Christian, or any other, faith. Brümmer writes that philosophical theology is clearly distinct from all natural theology, "in which an attempt is made to provide 'a conceptual grounding for the faith such that its rationality and the irrationality of its denial can be demonstrated.' We have argued that philosophical theology does not demonstrate what must be believed. It merely tries to limit the conceptual options to those that can be accepted without contradiction. In the end the decision as to which of the coherent options we are to choose has to be taken on other grounds (religious, ideological, personal, etc.) than those appealed to by philosophy. Faith cannot be derived from (or 'based on') philosophy" (1992:30). He thinks that philosophical theology should follow Wittgenstein in a refusal to make philosophy the provider of foundations and justifications (1992:2).

So natural theology attempts to demonstrate what must be believed about God on grounds acceptable to all people, but philosophical theology does not attempt to prove anything; it merely aims to delimit what beliefs about God and other religious matters people might hold without contradiction. Once we have these coherent sets of beliefs, which philosophers put forward as innovative proposals, the job of philosopher is over. Things from there onward become a matter of personal theology or personal faith.

But, and here comes my worry, is this not - even if we were to reject natural theology - to reduce fatally the scope of what philosophers of religion could and should do? Once we have established the meaning and coherence of certain religious beliefs and their connection to other religious beliefs, I think philosophers should go further and ask whether it is rational to accept these beliefs in the first place; and, if not, should consider what religious people might believe instead. The final decision whether we should accept any of these beliefs has, of course, to be taken by religious believers themselves. The epistemic proposals, as well as the conceptual proposals, which philosophers put forward, become a matter of personal theology or personal faith at the end of the day.

I am hereby arguing that philosophers of religion should not just do philosophical theology, but should also engage in rational theology. I suggest that we define this latter in the following way:

1. Rational theology is the attempt to assess, and if possible to justify, the rationality of religious faith, belief or commitment. 
Whereas philosophical theology attempts to test the coherence of doctrinal claims, their implications and their connection to other doctrinal claims, rational theology attempts to test the rationality and warrant of these doctrinal claims and to explore their connection to philosophical, scientific, political and moral claims. Philosophical theology only delimits conceptual options; rational theology suggests which options (if any) we should pick and embrace.

The question now to be considered is whether Brümmer's arguments against natural theology also undermine rational theology, so that we, after all, are stuck merely with philosophical theology. Brümmer maintains that there are two particularly serious objections which natural theology faces.

The first is that the "more natural theology seeks to base its concept of God on universally compelling grounds the more abstract and empty does this concept become, whereas every attempt to fill in the concept of God in specific concrete ways requires an appeal to specific religious traditions that are not universally compelling ..." (2006:201). This is disastrous, because the concept of God, like all other concepts, derives its meaning from the form of life in which it is employed, and therefore, when divorced from this context, is either misconstrued or meaningless.

The second problem with natural theology which Brümmer points out is this: it must fail in principle in what it sets out to prove, since the claim that God exists is not the sort of claim that can be proved or disproved on universally compelling grounds. In Popperian terms, we can say that belief in God is a metaphysical presupposition and not a scientific hypothesis (2006:202). In Wittgensteinian terms, we could say that the existence of God is a tacit presupposition which is constitutive for the theistic form of life. Brümmer writes: "I logically cannot claim to live my life in fellowship with God without at the same time presupposing the existence of the God in whose fellowship I live, nor can I logically understand my experience of the world in terms of the agency of God without at the same time presupposing that there is a God in terms of whose agency my existence can be said to make sense. In this way Christians have traditionally claimed that for them the existence of God is not contingent but necessary. Thus J. N. Findlay is correct in pointing out that for believers partaking in the theistic form of life and understanding, God's 'non-existence must be wholly unthinkable in any circumstances'" (1999:93). There is thus a difference of principle between science and religion, since truth claims in the context of religion differ from truth claims in the context of science: the latter remain empirical hypotheses which are methodologically subjected to doubt and conjecture regarding their probability or relative likelihood; whereas in religion this is not so, or, one might go so far as to say, it is impossible for this to be so. It follows that a natural theology is completely misguided. But it also follows "that within the context of the theistic form of life and understanding, the claim that God exists is not only rational but also necessary" (1999:93).

Now rational theology neither demands that the concept of God must be abstracted from its context nor requires that the only reasons allowed in a discussion about the rationality of belief in God must be universally compelling. This is good, because few philosophers these days believe that the reasons one can offer for or against belief in God are coercive, that is, are such that they would or should force anyone who understands them to share them. These arguments are in this respect like almost all philosophical arguments. The Enlightenment project was in this sense harbouring an unrealistic dream. Philosophy is today understood to be a dialogue between people of differing perspectives. The goal is, as in the days of the Enlightenment, to attain agreement, but agreement (a shared foundation) is not a precondition for doing philosophy. There are in philosophy no, or very few, reasons that all rational people should be convinced by. But that should not stop someone from arguing that it is rational (or irrational) to believe in God and ask the rest of us why we do not consider the reasons advanced to be coercive. 
Brümmer's second objection against natural theology does, however, seem to cause a problem for rational theology. His idea is that natural theology must fail in principle in what it sets out to prove, since the claim that God exists is not the sort of claim that can be proved or disproved, because God is a presupposition for the theistic form of life and that therefore God's non-existence is wholly unthinkable in any circumstances. With reference to rational theology, what causes the problem is not that rational theology must have the intention to prove or disprove the existence of God, but its assumption that it is reasonable also for believers to doubt the existence of God and to consider reasons for and against such a belief. Thus, such an enterprise presupposes that God's non-existence is not wholly unthinkable in any circumstances. Therefore, if Brümmer is right, philosophers of religion must be satisfied with the task of limiting what beliefs about God people can hold without contradiction (doing merely philosophical theology), because they cannot engage believers critically and constructively in a discussion about the presupposition of their religious form of life.

But is it actually the case that within the context of the theistic form of life, belief in God is not only rational but also necessary? Charles Taylor thinks that "belief in God isn't quite the same thing in 1500 and 2000" (2007:13). ${ }^{3}$ We have moved from a society where belief in God is unchallenged and unproblematic to a society in which such belief is understood to be one option among others, and possibly even a dangerous option. We are no longer certain (or as certain as we use to be) that God exists. People might believe in the same God, but they will typically not hold this belief as firmly as they used to do. Taylor also understands his own Christian faith in this way: "We [as religious believers] live in a condition where we cannot help but be aware that there are a number of different construals [of human flourishing], views which intelligent, reasonably undeluded people, of good will, can and do disagree on. We cannot help looking over our shoulder from time to time, looking sideways, living our faith also in a condition of doubt and uncertainty" (2007:11). So, traditionally speaking, Brümmer might be right, but it seems that nowadays many religious believers really have started to think that it could be true that God does not exist (not only as a purely logical possibility but as a live-option - as an existential possibility), or even that there is a certain likelihood (albeit a low one) that this is the case.

But, within the context of the theistic form of life, ought it not to be the case that belief in God is understood not only as rational but also as necessary? Maybe Brümmer on this point is putting forward a reasonable innovative proposal. He would then invite us to see whether we could share his conceptual proposal. ${ }^{4}$ We should take this option seriously and consider the reasons he gives. I personally prefer not to set up an ideal religious believer or an ideal theistic form of life in this way, but to proceed on the assumption that there are many different, but yet legitimate, ways of being religious or Christian. And this is certainly something we can argue about within rational theology!

Brümmer's philosophical theology project has been of utmost importance for philosophers of religion, and will continue to be so for the next generation of such scholars. I nevertheless hope that they will not merely do philosophical theology, but will also engage in rational theology. This is because there are important epistemic questions that need to be addressed and which go beyond the conceptual issues which Brümmer has so successfully dedicated his academic life to solving. Whereas philosophical theology attempts to test the coherence of doctrinal claims,

3 Whereas Taylor seems to assume that this "titanic change in Western civilization" says something of specific reference to belief in God, Peter Berger thinks it applies to belief and certitude in general. His thesis is that the pluralistic situation relativizes competing belief and value systems and deprives them of their taken-for-grantedness. Plurality affects not just what people believe but how they believe (Berger 2010).

4 This has also been his explicit response to the charge that he has offered false or implausible descriptions of religious language games or theistic forms of life (Brümmer 1999:96). 
their implications and their connection to other doctrinal claims, rational theology attempts to test the rationality and warrant of these doctrinal claims and to explore their connection to philosophical, scientific, political and moral claims.

\section{BIBLIOGRAPHY}

Berger, Peter (ed.), 2010. Between Relativism and Fundamentalism. Grand Rapids: Eerdmans. Brown, James Robert, 2001. Who Rules in Science. London: Harvard University Press.

Brümmer, Vincent, 1992. Speaking of a Personal God. Cambridge: Cambridge University Press.

Brümmer, Vincent, 1999. "How Rational is Rational Theology? A reply to Mikael Stenmark," Religious Studies (35):89-97.

Brümmer, Vincent, 2006, Brümmer on Meaning and the Christian Faith. Aldershot: Ashgate.

Dummett, Michael, 2010. The Nature and Future of Philosophy. New York: Columbia University Press. Grim, Patrick, 2007. "Impossibility Arguments," Michael Martin (ed.), The Cambridge Companion to Atheism. Cambridge: Cambridge University Press.

Haack, Susan, 1996. "Preposterism and Its Consequences," Social Philosophy and Policy Foundation (13):296-315.

Herrmann, Eberhard, 1995. Scientific Theory and Religious Belief. Kampen: Kok Pharos.

Herrmann, Eberhard, 2004. Religion, Reality and the Good Life. Tübingen: Mohr Siebeck.

Herrmann, Eberhard, 2007. "Religion without Metaphysics," Studia Theologica (61):163-83.

Kitcher, Philip, 2010. “Militant Modern Atheism," Journal of Applied Philosophy (10):1-13.

Morris, Thomas V. (ed.), 1988. Divine and Human Action. Ithaca: Cornell University Press.

Plantinga, Alvin, 1984. "Advice to Christian Philosophers," Faith and Philosophy (1):253-71.

Plantinga, Alvin, 2000. Warranted Christian Belief. Oxford: Oxford University Press.

Pyle, Andrew, 1999. "Michael Dummett," Key Philosophers in Conversation. London: Routledge.

Rundle, Bede, 2007. "Problems with the Concept of God," Chad Meister and Paul Copan (eds.), The Routledge Companion to Philosophy of Religion. London: Routledge.

Searle, John, R., 2004. Mind: A Brief Introduction. New York: Oxford University Press.

Stenmark, Mikael, 1995. Rationality in Science, Religion and Everyday Life. Notre Dame: University of Notre Dame Press.

Stenmark, Mikael, 1998. "The End of the Theism-Atheism Debate? A Response to Vincent Brümmer," Religious Studies (34): 261-80.

Stenmark, Mikael, 2001. Scientism: Science, Ethics and Religion. Aldershot: Ashgate.

Stenmark, Mikael, 2004. How to Relate Science and Religion. Grand Rapids: Eerdmans.

Taylor, Charles, 2007. A Secular Age. Cambridge: Harvard University Press.

\section{KEYWORDS}

Brümmer

Epistemology

Herrmann

Philosophical Theology

Rational Theology 